\title{
THE MULTIMODAL LEARNING AS A STRATEGY FOR CHEMISTRY REPRESENTATIONS CONVERSION: THE PHENOMENON TO THE CHART
}

\author{
Dirceu Donizetti Dias de Souza, \\ Maria Fernanda Moreira, Agnaldo Arroio \\ Faculty of Education, University of Sao Paulo, Sao Paulo, \\ Brazil
}

\begin{abstract}
Go through multiple ways of representation constitutes an essential skill to recognize, understand and explain numerous phenomena on the natural sciences and simultaneously relating them to the social and technological aspects that permeate the contemporary society. This integration of meanings becomes particularly relevant when the forms of representation are Cartesian systems, which add, among others, opportunities to build inferences and predictions during its production or reading. The learning that focuses the movement between these multiple forms of representation is not innate and dependent on teaching strategies that provide and encourage this practice. Learning strategies that consider aspects that combine multimodal oral narratives, texts and numbers, visual and audiovisual language are powerful tools that are available to be inserted into instructions in chemistry classrooms. These strategies allow the teacher to establish the initial skills and their evolution throughout the process regarding the ability of students to construct graphs representing the phenomena studied in the conceptual and analytical perspective. In this work are presented and discussed the results of evolution in the form of representation of Cartesian graphs for high school students before and during the process of multimodal learning. At the beginning of the process the students build their charts showing only a superficial view of the subject, merely just plot the data between two axes. Throughout the process students moves from a practical copyist to an explicit vision essential to a practice in which the relationships and conceptual analytical view about the phenomenon are considered.
\end{abstract}

Key words: chemistry, graphs, multimodal learning.

\section{Introduction}

Learning about chemistry demand cognitive processes that are not only capable of presets (Vygotsky, 2001; Duval, 2009), thus requiring the development of structures related to general skills, which require the use of representation and expression systems that are beyond the natural language (Duval, 2009), and these systems have become the target of research where there is a concern in the use of multiple languages (verbal, visual, numeric), which contributes to the procedure concerned (Kozma \& Russell, 1997).

Researches in the last few years suggests that the chemical knowledge is raised as a whole, expressed and forwarded in three different ways, which are characterized by visible plans, not visible, and symbolic (Gilbert \& Treagust, 2009; Johnstone, 1991, 1993, 2000, Treagust; Chittleborough \& Mamiala, 2003), directly impacting on learning that normally occurs based on the integration of meanings built through several modalities, in 
which are combined oral narratives, texts, numbers, visual language, and involves the conversion of information among the various representation systems (Lemke, 2006, Jewitt et al, 2001), and often need to be extrapolated to understanding buildings in the Cartesian system (Duval, 2003).

Research also indicates that students do express difficulties in moving between these different modes of representation (Gabel, 1998, 1999; Hinton \& Nakhleh, 1999), especially when referring to Cartesians graphical representations, therefore the construction of graphs for representations of phenomena is a plausible option as study content within the school environment, as they help to shorten, rearrange and expose information that is implicit in the phenomena, clarifying archetypes of significant covariation between the magnitudes involved, making it possible to build inferences (García García \& Perales Palacios, 2007; Lemke, 1998; Bastide, 1990; Anderson \& Helstrup, 1993; Schnotz \& Banert, 2003).

Spite of its importance, the investigations that have been developed over the past fifteen years with regard to the graphical representations, focused mainly on how they are interpreted and assimilated by students (Camargo Filho, Laburu \& Barros, 2011) by limiting the degree of comprehensiveness of the understanding from cognitive processes wrapped around this theme, although several recent studies reconfirm the need to expand the graphic literacy (Postigo \& Pozo, 1999, 2000; Nass, 2008), which implies the necessity to expand the knowledge about the restrictions exhibited by high school students in the construction of such representations in chemistry classes.

The studies about the graphics interpreter show that students have a superficial view of the matter, limiting itself to plot the data between two axes (Postigo \& Pozo, 1999; Camargo Filho, Laburu \& Barros, 2011), that is the students follow the tendency to retain a enhanced targeting on data and in the text presented and, when they are challenged with the need to transcribe and build a model for the situation, they exhibit difficulties of running (Kintsch, 1998; Léon, 1999).

A restrictive aspect that contributes to the learning difficulties in the construction and interpretation of graphical representations is due to their own didactic books, which include numerous representations, but that frequently are used as mere illustrations, without being explained the processes of interpretation and construction of the significance of such representations (Postigo \& Pozo, 2000; De Vries \& Lowe, 2010), and also the interpretation of graphs and its production requires students to deploy different levels of information processing employing an approach that addresses in form and function to expectation advocated and that is based on aspects implicit, explicit and conceptual, which depends not only on the student's ability to decode the graphical syntax, but also the ability to establish a relationship with the phenomenon that will be represented, and the specific characteristics required by the graph (Postigo \& Pozo, 2000). Clear examples of this situation are the graphs representing the chemical equilibrium between reactants and products from a chemical reaction.

Berg and Smith (1994) argue that there is very little student participation in such activities and because of this ability being basic, but not innate, nor from spontaneous development; it must be subject to appropriation in the teaching in school. From this finding, there are indications of that the professor is the largely responsible for producing activities that aid in the student learning in different modes of representation (Tan et al., 2009).

Given of the foregoing, to the reflective teacher who is developing their teaching activities in the classroom, it is worth asking how it can be established a turning point that 
allows the organization of content, which contribute to the advancement of learning in their students in the topic concerned.

Among several strategies that can be used in the classroom, in order to enable the student a learning that contemplates the contents of submicron chemistry mode, and also in the macroscopic and symbolic ways, it highlights the use of activities involving multimodal aspects, that is, the use of activities that include not only verbal language, but also the use of games, experiments and numerical language which makes them essential in the context of multiple representations enabling the expansion of the dimensions addressed in learning.

The issue of multimodality in view of the multiplicity of representations in natural sciences (Prain \& Waldrip, 2006) has been the object of attention of the academic community and called "the third wave of scientific literacy" (Klein \& Kirkpatrick, 2010) and from this perspective the graphics constitute a significant proportion of this symbolism, which aid the representations of numeric and quantitative relationships between variables in space (Postigo \& Pozo, 2000), revealing itself as an effective way for the movement of descriptive and analytical information, which enable the reader the immediacy of understanding about the subject.

A multimodal strategy of education plays an important role as it can represent a tool for developing this competence allowing transpositions between the different modes of representation and different contextual assumptions (Knain, 2006).

Conceptualize learning mediated by multimodality as one that is favored by the practice of multiple forms of the expression of school-scientific principles, or principles from Science, Technology, Society and Environment (STSE), in which there is the traffic between manual or practical activities (experiments, games or artifacts, computermediated or not) the word (spoken or printed) and images (illustration, photo, map, chart, graph, equation, animation, video etc..).

In the proposal of the multimodal learning the student becomes involved with three important cognitive processes. The first is the selection process; the student makes contact with the selection of verbal and visual information to obtain base information. After this procedure, the student needs to organize information from various ways (visual, verbal) to be able to create explanations about them. Finally, the student needs to integrate/connect the different types of information available to him to build up mental representations (Mayer, 1997).

In this direction, it is seen that multimodal learning is an important tool to establish meaningful knowledge in the dynamic interaction between different languages (verbal, visual, numeric, etc.). It is also important to highlight that these languages can be used to meet different aspects of meaning, that is, perform different functions in learning. Therefore, the use of multimodality in teaching chemistry has numerous advantages over unimodal focused only on teaching a language, predominantly in speech or writing.

After noting the possibility of using the strategy of multimodal learning in class about chemistry, comes the need to understand how high school students moving through the conversion of representations before and after exposure to this strategy in the study of concepts about chemistry. This question is configured as the central goal of this research work.

In this work the proposal is to verify the development on the skills and abilities of students in the conversion of drawings after approximately one year of exposure to multimodal strategy work in which these students have participated in at least three research activities. 


\section{Methodology of Research}

The participants of this investigation are Brazilian students of regular school, with a mean age amongst 16 to 17 years, who attend classes in the morning period at a public school in the city of São Paulo.

Early in the second year of middle school $\left(11^{\text {(th) }}\right.$ grade $)$ the students begin to participate in a project of designed classes in the multimodal perspective, so their experience until this moment is related to unimodal classes, that is, the learning of content is based on the speech and writing.

As a way of characterizing the competencies and skills displayed by the students for conversion of representations, it is requested that each student individually build from a tabulated data, a chart that represents the phenomenon of density variation as a function of temperature and justify their choices on features specific to the construction of the graph, the graphical syntax (rules governing construction) and establish relationship with the phenomenon that is being represented, making this activity a pre-test.

Over the subsequent year were offered to the students constructed three activities in the inquiry learning perspective, which enable the simulation of this phenomenon, data collection, organization of data, and their representations in many different forms.

The activity that was used to compare the evolution of skills and abilities in the conversion of representations took up introductory notions about chemical equilibrium. In this activity the students mimicked a game in which over time the reactants are consumed and the product is formed to the stabilization of the concentration amongst the reactants and the product.

From the collection of the evidences, the students built tables, graphs and mathematical equations establishing relations with the phenomenon studied and the results were presented as an activity report, which thus constitutes a post-test.

The data obtained from the graphs (pre-test) and activity reports (post-test) will be analyzed based on the levels of the conversion of domain representations, adapted from the levels of increasing learning difficulty and reading charts, proposed by Postigo \& Pozo (2000) and are shown in Table 1.

Table 1. Levels of the domain information for constructing graphs.

\begin{tabular}{|c|c|}
\hline Domain Level & Description \\
\hline Explicit & Only the elements that constitute the images are recognized. \\
\hline Implicit & $\begin{array}{r}\text { It identifies relationships between variables and use the symbols and } \\
\text { legends in the correct way. }\end{array}$ \\
\hline Conceptual & $\begin{array}{r}\text { Conclusions, explanations and predictions related to the phenomenon } \\
\text { are established in the construction of the chart. }\end{array}$ \\
\hline
\end{tabular}

To subsidize the guidelines of data on the levels of the conversion domain the representations of the following factors will be assessed:

1. Types of graphs.

2. Presentation graphics and formatting (title and had the variables were explicit in referring axes).

3. Domain concept of dependent and independent variable (linear mathematical function).

4. Domain concept of scale of the axes X and Y.

5. Correlation of the chart with the concept of the phenomenon represented. 


\section{Results of Research}

The results obtained in the pre-characterizing test charts produced by the students are displayed in table 2 .

The results of the pre-test indicate that all of the students has no domain to establish the necessary scale between the $\mathrm{X}$ and $\mathrm{Y}$ axes and do not establish a correlation between the graphical representation and studied phenomenon.

Table 2. Results of the pretest.

\begin{tabular}{|c|c|c|}
\hline \multicolumn{2}{|c|}{ Categories of analysis } & $\begin{array}{c}\text { \% of the students who attended } \\
\text { the categories of analysis }\end{array}$ \\
\hline \multirow{2}{*}{ Chart Type } & XY & 86 \\
\cline { 2 - 3 } Presentation & Bar & 14 \\
\cline { 2 - 3 } & Title & 54 \\
\cline { 2 - 3 } & Density unit & 83 \\
\hline $\begin{array}{c}\text { Dominion of the concept of dependent and independ- } \\
\text { ent variable (domain and image of linear mathematical } \\
\text { function). }\end{array}$ & 17 \\
\hline Dominion of the concept of scale of the axes X and Y. \\
\hline $\begin{array}{c}\text { Correlation of the graph with the concept of the phe- } \\
\text { nomenon represented. }\end{array}$ & 0 \\
\hline
\end{tabular}

Figures 1, 2, 3 and 4 are examples of standard graphical representation of the phenomenon of density variation as a function of temperature in the pretest.

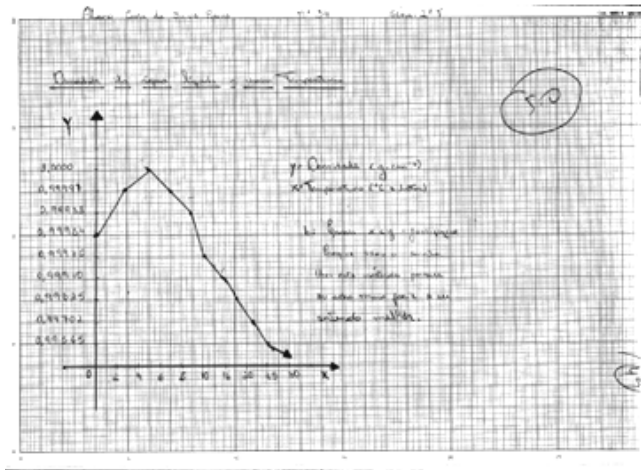

Figure 1: Standard A

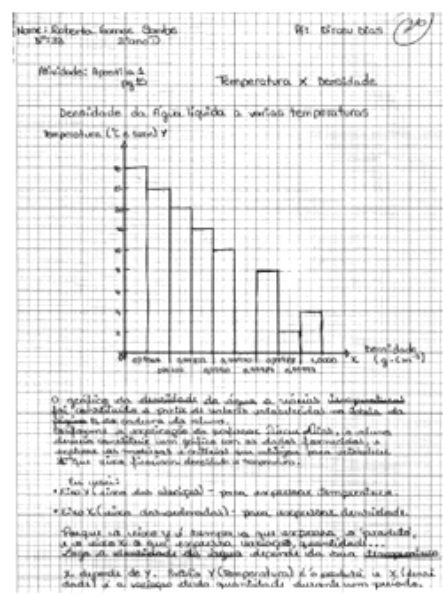

Figure 2: Standard B 


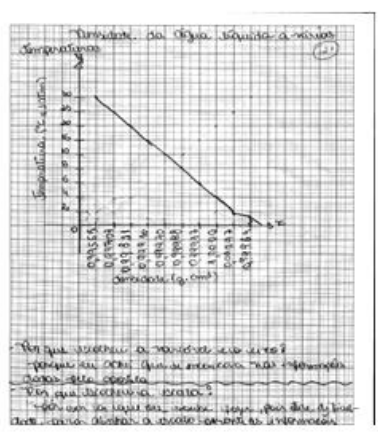

Figure 3: Standard C

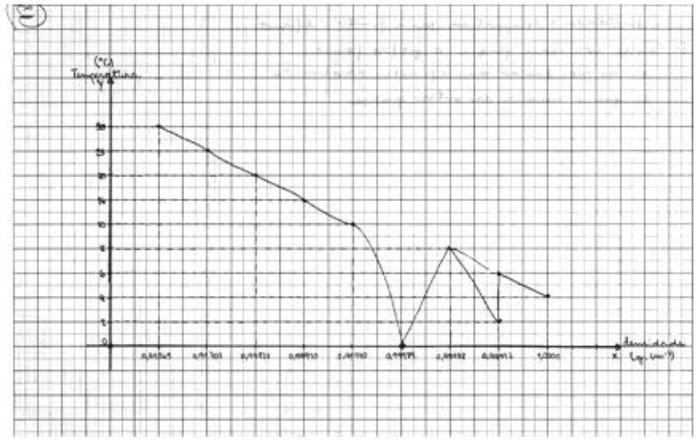

Figure 4: Standard D

The standard visually approximates the appropriate result for representation. Standards B, C and D are inadequate representations to the studied phenomenon. The results of the post-test which characterize the graphs produced by the students are displayed in table 3 .

Table 3. Results of the post-test.

\begin{tabular}{|c|c|c|}
\hline \multicolumn{2}{|c|}{ Categories of analysis } & $\begin{array}{c}\text { \% of the students who attend- } \\
\text { ed the categories of analysis }\end{array}$ \\
\hline \multirow{2}{*}{ Chart Type } & XY & 100 \\
\cline { 2 - 3 } & Bar & 100 \\
\hline \multirow{2}{*}{ Presentation } & Title & 100 \\
\cline { 2 - 3 } & Concentration unit & 100 \\
\cline { 2 - 3 } $\begin{array}{c}\text { Dominion of the concept of dependent and independent } \\
\text { variable (domain and image of linear mathematical func- } \\
\text { tion). }\end{array}$ & 100 \\
\hline \multicolumn{2}{|c|}{$\begin{array}{c}\text { Dominion of the concept of scale of the axes X and Y. } \\
\text { Correlation of the graph with the concept of the phe- } \\
\text { nomenon represented. }\end{array}$} & 100 \\
\hline
\end{tabular}

The results of post-test indicate higher values in all categories of analysis mainly in the domain and image of the linear mathematical function, the concept of scale and the correlation of the concept about the phenomenon and its Cartesian graphing.

Figures 5a and 6a are examples of alternative graphical conversion of representation of the concept of chemical equilibrium versus time and Figures $5 \mathrm{~b}$ and $6 \mathrm{~b}$ are examples of segments texts establishing the correlation of the graph with the concept studied in the post-test. 

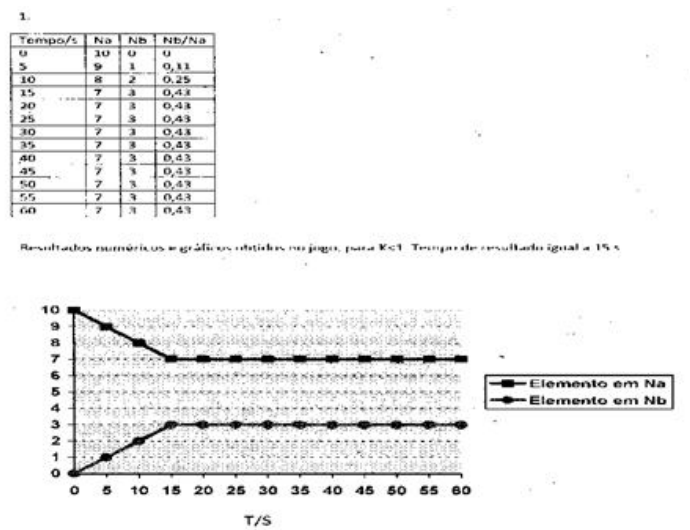

Figure 5a: Chemical equilibrium.
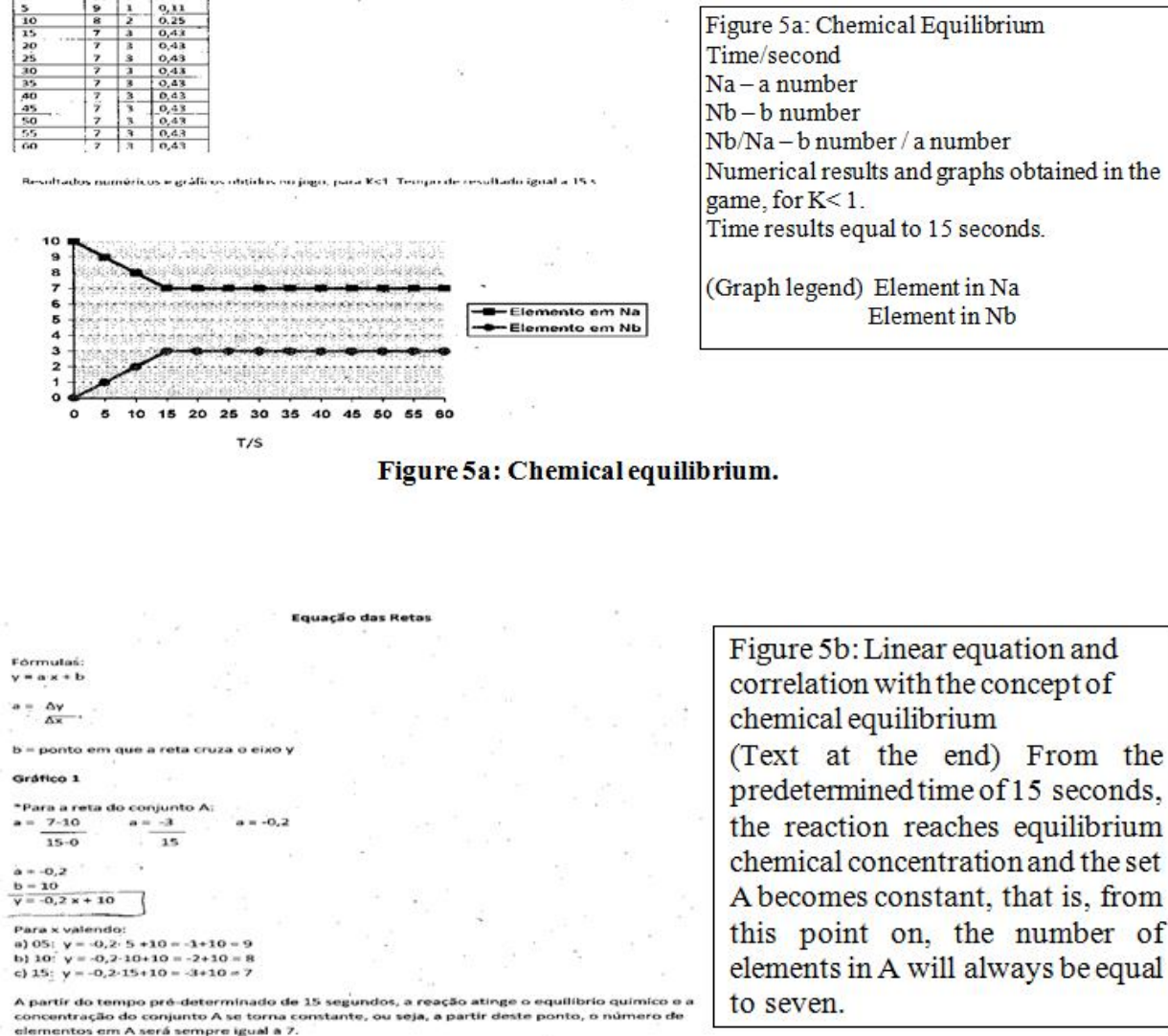

Figure 5b: Linear equation and correlation with the concept of chemical equilibrium

(Text at the end) From the predetermined time of 15 seconds, the reaction reaches equilibrium chemical concentration and the set A becomes constant, that is, from this point on, the number of elements in A will always be equal to seven.

\section{Figure 5 b: Linear equation and correlation with the concept of chemical equilibrium.}

In Figure 5a is represented the table of the data obtained during the game which relates the consumption of the reactant $\mathrm{A}$ and product $\mathrm{B}$ and the formation of mathematical ratio there between, establishing the concept of chemical equilibrium after 15 seconds and the time graphic representation of this concept .

In figure $5 \mathrm{~b}$ has been proposed a mathematical equation that is supposed to represent the concept and its explanation (From the predetermined time of 15 seconds, the reaction reaches equilibrium and the concentration of the chemical set A becomes constant, that is, from this point the number of elements in A will always be equal to 7). 

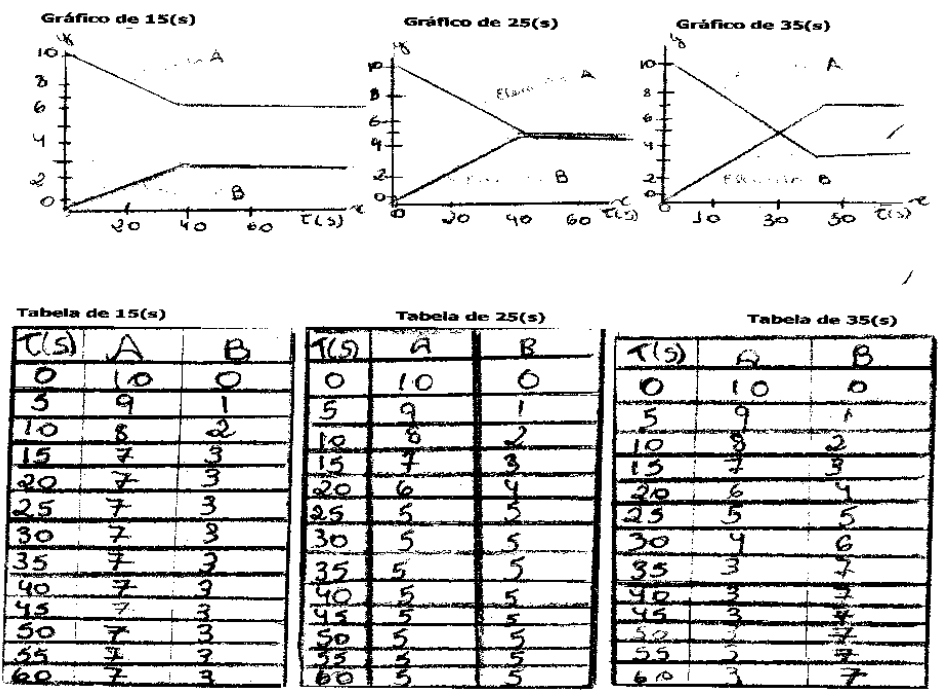

Figure 6a: Chemical Equilibrium.

Resultados:

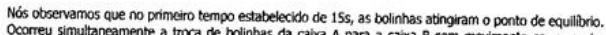
Ocorreu simultaneamente a troca de bolinhas da calica A para a caixa B com movimento constante das

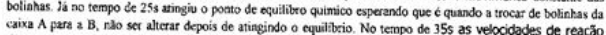

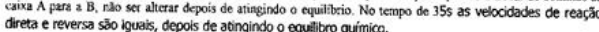

Discussáo:

O conceito de equilibrio quimico fot compreendido através do jogo: as bolinhas de isopor representando os reagentes e produtos de uma reacrio quimica nos aiudaram a entender cono a trora de derentos constitui uma situaç̧ŏ de equilibrio em uma reaçāo química. Estabelecemos que os reagentes formus os produtos, e vice-versa, quando essa troca ocome, e que variaçbes de ternpo, entre outras varidiveis possiveis, słă importantes para o equitibrio de una neaçăo.

Este resultado ilustrou tambenn como um jogo simples pode senvir como analogia a um conceito quimico básico.

Conclusāo:

Coricluimos neste trabatho o conceito da reaçăo de equilbrio quimico, onde pegamos algumas bolas de isopor, que representavam os elementos químicos e duas caivas, que representavam os produtos e os

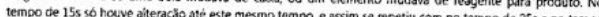
de 35s Quando a reasbo chegou ao tempo de 255 atingilu o equilbrio quimico no tompo de 255 e no tempo

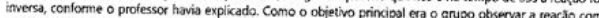
clareza, podemos dizer que o objetivo foi realicado com sucesso e que conseguimos visualizar a conceito de equilibrio quimico.

\section{Results:}

We observe that in the first set time of 15 seconds, the balls reached the equilibrium point. Occurred simultaneously the exchange of the marbles of the box A to box B with the constant movement of the marbles. Already at the time of 25 seconds was reached the chemical equilibrium is expected that when the balls are exchanged of the box A to box B, and they do not change after balance. At time 35 seconds the speeds of the forward and reverse reactions are equal, after reaching chemical equilibrium.

\section{Discussion:}

The concept of chemical balance was understood through the game, the Styrofoam beads representing the reactants and products of a chemical reaction helped us to understand how the exchange of information constitutes a situation of a chemical balance. We have established that the reactants form products and vice-versa and when this change occurs, and that variations in time, among other possible variables are important for reaction.

This result also illustrated as a simple game can serve as an analogy to a basic chemical concept.

Conclusion:

We conclude that in this study of the concept of chemical reaction, where we took some Styrofoam balls, which represent the chemical elements and two boxes, which represent the products and reactants. Every 5 seconds a ball box changed or shifted one element of reactant to product. At time 15 seconds, until it was no change only once and thus repeated until time of 25 seconds and time of 35 seconds. When the reaction time reached 25 seconds, reached chemical equilibrium, and the time $35 / 2$ the reaction was reversed, as the professor had explained As the major goal of the group was clearly observe the reaction, we can say that the goal was successfully accomplished and we can visualize the concept of balanced.

Figure 6b: Correlations with representations of the concept of chemical equilibrium.

In figure 6a the graphics are related to their tables containing the complete set of data in which the chemical balances are obtained after $15 \mathrm{~s}, 25 \mathrm{~s}$ and $35 \mathrm{~s}$.

In figure $6 \mathrm{~b}$ are proposed the interpretations of the results and the correlations are established with the concept studied. 


\section{Discussion}

The characterization of graphs produced by student groups is of central importance in planning and organizing of the activities of the classroom of chemistry therefore directs the teacher to the possible challenges faced throughout the cycle of the high school.

There are rare cases in which the student is unaware of the nature of the chart type to be built and the teacher must be alert to the appropriate guidelines and concrete clarifications, even for presenting the students samples of the types of graphs and its applications, since, as can be seen in Table 2, $14 \%$ of students presented their constructions using the sort bar graphs, in disagreement with the guidelines expressed in the classroom.

The other categories of analysis of the sample refer to the presentation, domain and image correlation and linear function of the graph with the concept studied.

These categories deserve special attention from the teacher, therefore, is not innate to the student the exact understanding of these characteristics, with little significant amount of students, only about $17 \%$ made explicit in their productions in the pre-test the concept of dependent and independent variable showing two possible hypotheses to explain this fact: no internalization of the graph it is a form of representation of the phenomenon, that is, the graph is just a place to plot numbers and plot a mechanical action resulting dimensionless and timeless moments of lived in classes or mathematical foundations, students start with the assumption that the reader is the teacher and he has knowledge about "what" the representation refers.

The relative lack of units to the phenomenon referred, namely, relations between density (g.cm-3) and temperature $\left({ }^{\circ} \mathrm{C}\right)$ may be an indication that reinforces the previous hypothesis, and that is, the teacher is the reader production.

The last category of analysis shown in Table 2 makes clear the foregoing and reinforces our hypothesis in relation to how students think when they are building their charts in the pre-test, that is, this action is restricted to the use of a space, in which numbers should be plotted and curves must be constructed, without establishing a clear link to a chart that is a way of representing a phenomenon which, to be properly represented must meet certain standards of construction, in which the $\mathrm{X}$ axis must represent the independent variable (field) and the $\mathrm{Y}$ axis to represent the dependent variable (image), corroborating studies Kinstch (1998) and Léon (1999).

A summary of the results detailed in Table 2 indicates that students build their graphics as simple graphics, without establishing any link between the phenomenon and the graphic form of representation, that is, the approach used by a significant portion of students in the construction of graphics, is based primarily on aspects explicit, that is, the pattern which emerges from our analysis of the graphics located more students at the surface of construction and forms of representation of these reading (Postigo; Pozo, 2000).

Moreover completely reverse situation is shown in Table 3, which summarizes the results after analysis of graphs and their explanations in the post-test.

All the samples show substantial evolution in the ways of thinking of the students, which express the meaning reconstruction of the graph, previously only seen as an area of plot numbers to a more evolved that involves the representation of the phenomenon studied.

This is a fairly consistent indicator that allows us to infer that the strategy of proposing activities involving multimodal learning in the classroom contributes significantly in the training of students who are showing higher levels of conceptual field of information which involves other dimensions, such as conclusions and explanations related to the phenomenon. 
The use of subtitles, the combination of tables and graphs in Figures 5a and $6 \mathrm{a}$ shows the new linkage for the conversion of imagistic representations.

In the case of Figures $5 \mathrm{a}$ and $5 \mathrm{~b}$ is shown that evolution in the forms of representation has advanced beyond the Cartesian graph form, ending with suggestions of mathematical equations which supposedly represent the stages of chemical equilibrium in a reaction.

\section{Conclusions}

The recent literature on representations of research in chemistry has been busy studying how students pass through different forms of representation, and many studies indicate that the teacher should focus their attention on the search for mechanisms that can assist in this task.

In this study conducted in a classroom with high school students in a regular public school indicates that when they are offered learning situations to consider multimodal learning the student has full condition to reconstruct their knowledge in the direction of thinking that carries a lot of common sense reproduction, that is, the student reproduces what the teacher observes run for an analytical way of thinking.

The way of thinking that involves only unimodal playback induces the learner to ignore important aspects in conversion of representations such as, title attribute to graphics, insert units in the respective magnitudes $\mathrm{X}$ and $\mathrm{Y}$ axes, and determine the domain of the function represented image, focus little attention to the proportional relationship between the ranges of values in the $\mathrm{X}$ and $\mathrm{Y}$ axes, and, moreover, does not contribute to the establishment of relations between phenomena and / or concepts and their representations, constituting a serious constraints to the process conversion of representations.

From the knowledge of these restrictions the teacher can organize their activities in the classroom, so that helps students overcome the basic standards of reading and interpretation, extending them to levels that allow the establishment of relations between interpret, explain and predict phenomena represented by graphs.

The construction activities to consider multimodal learning, as demonstrated in the results presented can make a decisive contribution to overcoming the constraints typically found in this field of activity.

\section{References}

Anderson, R. F., \& Helstrup, T. (1993). Visual Discovery in mind and on paper. Memory and Cognition, 21 (3), 283-293.

Bastide, F. (1990). The iconography of scientific texts: Principles of analysis. En Lynch, M. \& Woolgar, S. (Eds.), Representation in Scientific Practice. Cambridge, MA: MIT Press.

Berg, C. A., \& Smith, P. (1994). Assessing Students' abilities to construct and interpret line graphs: disparities between multiple - choice and free - response instruments. Science Education, 78 (6), 527-554.

Camargo Filho, P. S., Laburu, C. E., \& Barros, M. A. (2011). Dificuldades Semióticas na Construção de Gráficos Cartesianos em Cinemática. Caderno Brasileiro de Ensino de Física, 28 (3), 546-563.

De Vries, E., \& Lowe, R. K. (2010). Graphicacy: What does the learner bring to a graphic? Paper presented at the EARLI SIG 2 Conference in Comprehension of Text and Graphics meeting, Tübingen, Germany.

Duval, R. (2009). Semiósis e Pensamento Humano: Registros semióticos e aprendizagens intelectuais. São Paulo, São Paulo, Editora Livraria da Física. 
Gabel, D. (1998). The complexity of chemistry and its implications for teaching. In B. J. Fraser \& K. G. Tobin (Eds.), International handbook of science education London: Kluwer Academic.

Gabel, D. (1999). Improving teaching and learning through chemistry education research: A look to the future. Journal of Chemical Education, 76 (4), 548-554.

García García, J. J., \& Perales Palacios, F. J. (2007). Comprenden los estudiantes las representaciones gráficas cartesianas presentadas en los textos?. Enseñanza de las Ciencias, $25,107-132$.

Gilbert, J. K., \& Treagust, D. (2009). Multiple Representations in Chemical Education. Dordrecht: Springer.

Hinton, M. E., \& Nakhleh, M. B. (1999). Students' microscopic, macroscopic, and symbolic representations of chemical reactions. The Chemical Educator, 4 (4), 1-29.

Jewitt, C., Kress, G., Ogborn, J. O. N., \& Tsatsarelis, C. (2001). Exploring Learning Through Visual, Actional and Linguistic Communication : the multimodal environment of a science classroom. Educational Review, 53, 5-18.

Johnstone, A. H. (1991). Why is science difficult to learn? Things are seldom what they seem. Journal of Computer Assisted Learning, 7, 75-83.

Johnstone, A. H. (1993). The development of chemistry teaching: A changing response to a changing demand. Journal of Chemical Education, 70 (9), 701-705.

Johnstone, A. H. (2000). Teaching of chemistry: Logical or psychological? Chemical Education: Research and Practice in Europe, 1 (1), 9-15.

Kintsch, W. (1998). Comprehension: a paradigm for cognition. Nova York: Cambridge University Press.

Klein, P. D., \& Kirkpatrick, L. C. (2010). Multimodal literacies in Science: Currency, Coherence and Focus. Research in Science Education, 1 (40), 87-92.

Knain, E. (2006). Achieving Science Literacy Through Transformation of Multimodal Textual Resources. Sciences Education, 90 (4), 656-659.

Kozma, R. B., Russell, J. (1997). Multimedia and understanding: Expert and novice responses to different representations of chemical phenomena. Journal of Research in Science Teaching, 34 (9), 949-968.

Lemke, J. L. (1998). Multiplying meaning: Visual and verbal semiotics in scientific text. In: Martin, J. R. \& Veel, R. (Eds), Reading Sciences.

Lemke, J. L. (2006). Investigar para el futuro de la educación científica: Nuevas formas de aprender, nuevas formas de vivir. Investigación Didática, 24 (1), 5-12.

León, J. A. (1999). Mejorando la comprensión y el aprendizaje del discurso escrito: estrategias del lector y estilos de escritura. In: Pozo, J. I. \& Monereo, C. El aprendizaje estratégico. Madrid. Santillana.

Mayer, R. E. (1997). Multimedia learning: Are we asking the right questions. Educational Psychologist, 32, 1-19.

Nass, D. P. (2008). Gráficos como representações visuais relevantes no processo ensino- aprendizagem: uma análise de livros didáticos de Química do Ensino Médio. 2008. Dissertação (Mestrado em Química Analítica) - Instituto de Química de São Carlos, Universidade de São Paulo, São Carlos, 2008. Available in: $<$ http://www.teses.usp.br/teses/disponiveis/75/75132/tde-11092008-151037/>. Retrieved in: February, 2012.

Postigo, Y., \& Pozo, J. I. (1999). Hacia una nueva alfabetización: el aprendizaje de información grafica. In J. I. Pozo \& C. Monereo (Coords.), El aprendizaje estratégico: enseñar a aprender desde el currículo. Madrid: Santillana /Aula XXI.

Postigo, Y., \& Pozo, J. I. (2000). Cuando una grafica vale más que 1.000 dados: la interpretación de graficas por alumnos adolescentes. Infancia y Aprendizage, 90, 89-110. 
Prain, V., \& Waldrip, B. (2006). An Exploratory Study o f Teachers' Use of Multi-modal representations of Concepts in Primary Science. International Journal of Science Education, 28 (15), 1843-1866.

Schnotz, W., \& Bannert, M. (2003). Construction and interference in learning from multiple representations. Learning and Instruction, 13 (2), 141-156.

Tan, K. C. D., Goh, N. K., Chia, L. S., \& Treagust, D. F. (2009). Linking the macroscopic, sub-microscopic and symbolic levels: The case of inorganic qualitative analysis. In J. K. Gilbert; D. Treagust (Eds), Multiple Representations in Chemical Education, Models and Modeling in Science Education. Netherlands: Springer.

Treagust, D. F., Chittleborough, G., \& Mamiala, T. (2003). The role of submicroscopic and symbolic representations in chemical explanations. International Journal of Science Education, 25 (11), 1353-1368.

Vygotsky, L. S. (2001). A Construção do Pensamento e Linguagem. São Paulo: Martins Fontes.

Received 27 September 2012; accepted 15 November 2012

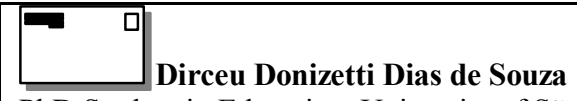

PhD Student in Education, University of São Paulo, São Paulo, Brazil

E-mail: baumcima@yahoo.com.br

Website: http://www.usp.br

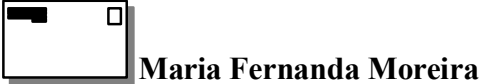

Pre-service chemistry teacher, University of São Paulo, São Paulo, Brazil

E-mail: maria.fernanda.moreira@usp.br

Website: http://www.usp.br

\section{\begin{tabular}{ll}
\hline Agnaldo Arroio \\
\end{tabular}}

$\mathrm{PhD}$, Associate Professor, University of Sao Paulo, Faculty of Education, Av. da Universidade 308, bloco A, sala 109., Butantã, 05508-040 São Paulo - SP - Brazil

E-mail: agnaldoarroio@yahoo.com

Website: http://usp-br.academia.edu/AgnaldoArroio 